\title{
Authentic materials in online teaching to improve students' involvement
}

\author{
Maria Dmitrievna Inkova*, Irina Valerievna Pronina, Ludmila Petrovna Timoshenko, Daria \\ Alekseevna Prusakova, and Yana Borisovna Adasova \\ Plekhanov Russian University of Economics, Foreign Languages Department №3, Moscow, Russia
}

\begin{abstract}
Online education is not an innovative product nowadays but when COVID-19 pandemic resulted in total lockdowns, many teachers and students registered numerous challenges in virtual classrooms among which the level of a teacher-student interaction is a focus of this paper. The research shows that isolation, distraction, and lack of immediate connection can actually pose a big problem. As a result, many students lose interest and become passive learners with poor performance. To revive scholars' involvement research was conducted integrating authentic materials in online classes. A quasi-experimental method was used to collect data. A questionnaire among the students allowed to consider their attitude to studying online while semi-structured interviews and self-written reflections provided rich material for analysis. On the whole, the study revealed positive gains. Being a natural source of practical English, authentic materials bring meaning back into the classrooms and offer teachers an inexhaustible source of relevant language. They help regain students' engagement if applied thoughtfully. Though there are certain difficulties, with due experience and practice they can be overcome. The results of this study contribute to providing useful guidelines for English teachers and students to enhance the efficacy of teaching and learning activities, particularly in virtual ELT (English Language Teaching) classrooms.
\end{abstract}

Keywords: online studying, learning motivation, meaningful context, authenticity

\section{Introduction}

The introduction of digital technologies into teaching began almost half a century ago, but till lately teachers around the world had a choice whether to apply them and to what extent. In the new pandemic reality educational environment had to digitalise to survive. This move was not unanimously advantageous and many teachers and students are still struggling to find their way in the tech world.

Although the pandemic brought forward numerous issues to be considered [1], this paper is going to narrow the focus on the problem of keeping the students involved while

*Corresponding author: Inkova.MD@rea.ru 
working online English classes. The results of the investigation into the reasons of loss of learners' motivation give further insights into restoring students' involvement as lack of real engagement in virtual classrooms disrupts ELT classes [2,3] and turns students into automated gap fillers and routine text-translators which does not contribute to the main aim in TESOL (Teaching English to Students of Other Languages). Although it may seem that the most important element in the course is mastering a set of language items arranged in a certain sequence, real success in English language teaching and learning is when learners can use the language meaningfully inside and outside classrooms [4].

Outside the classroom we have conversations, listen to popular streamers, watch movies, write emails, or longer texts. Some people read professional books and journals; attend conferences where they have professional contacts. People conduct all these activities not just to practice the language; attention is focused on the information, opinions, ideas [5]. So, professional or personal interest in the activities is the key issue. The consequent conclusion is that authentic materials are a natural solution to many problems of students' involvement.

There is a big number of studies conducted in the recent years on benefits of using authentic materials in ELT. Harmer [6] remarks that these types of input help students improve their language production, acquire the language in an easier manner, and increase their confidence. Peacock [7] claims that authentic materials may increase learners' levels of on-task behavior, concentration, and involvement in the target activity. Hedge [8] states that real tasks help students understand authentic language of the real world. Here we cannot but support this approach as authentic materials provide a natural model of the language and contribute to forming learners' communicative competence. We are also strongly convinced that modern circumstances of total virtual teaching and lack of students' motivation provide a completely new background for authentic teaching.

The significance of using authentic materials in online class is going to be reviewed in this research. The first aim is to consider the difficulties with students' involvement teachers face at online classes. The second aim is to demonstrate that authentic materials integrated in the online lesson provoke a positive change in the dynamics of the virtual classroom. Teachers can use it as a powerful tool to engage the full potential of learners' communicative competence and learning motivation.

\section{$2 \quad$ Materials and methods}

The present study uses a descriptive approach in combination with self-written reflections and semi-structured interviews. This kind of approach allows the researchers to depict the situation with an in-depth understanding of a particular phenomenon. The study was carried out in the context of EFL teaching at university level during the Covid-19 pandemic among the students of economic courses at Plekhanov Russian University of Economics and involved 60 learners and 5 instructors. The self-reflection consisted of 5 questions examining the respondents' views and ideas on virtual English language classes. It was distributed among the participants to reveal their perceptions and experience about online studying. Considering the pandemic situation, it was conducted online using Google forms. The method of self-written reflection as an instrument of data collection was used because it allowed profound analysis and self-study. The collected data were tabulated and classified on the basis of the research questions. The semi-structured interviews provided a further insight into the problem and helped collect valuable individual experience. 


\section{$3 \quad$ Results}

The results of the questionnaire prove that students mostly lose interest and motivation while studying online which makes all other things useless. Only a small number of the respondents show the same involvement and regard their remote learning as satisfactory or even successful. At the same time the majority of the scholars, $92 \%$, assessed digital classrooms as nonbeneficial and tedious.

There are several reasons for this. The first one is isolation, $64 \%$ of the participants tested positive at this point. Without the usual routine of the classroom setting and the supportive company of other scholars it is no surprise that some students may start feeling a strong sense of isolation that slowly erodes their desire to learn. Lack of immediate company may significantly undermine students' engagement and motivation.

Further issue of concern is a lot of distractors. In the classrooms, everything creates a productive educational environment. Moreover, if there appear some intruders a teacher can have a relative control over the situation and react quickly on what is going on. But at their bedroom or kitchen tables together with other relatives present and with their devices on with a lot of resources for fun, students may find it difficult to resist the temptation and concentrate on the classroom activities. This situation will require a genuine interest to stay on. The research registers $59 \%$ of students who find this issue applicable to their experience.

One more challenge is the lack of face-to-face communication. It becomes a real obstacle in a virtual class. Learners may feel disoriented and disconnected from their instructor as well as their peers. They may struggle with comprehension, lose confidence, and as a result, they quickly lose interest in such activities. This is the complaint of $71 \%$ of the respondents.

So, in the given conditions a group of teachers decided to implement authentic materials to regain the students' motivation in a virtual classroom. The teachers selected proper original materials in open sources revealing the studied topics and offered students to analyse them from informative and linguistic points. Students noticed new structures and vocabulary and practiced using them in productive tasks aimed at discussion of the main ideas and covert messages. As round-up students were offered to investigate into the topics further and prepare group presentations. The results of data analysis obtained from both self-written reflections and semi-structured interviews registering learners' reaction and engagement reflect various aspects related to the authentic materials impact on students' overall involvement.

In general, students had a positive attitude to the authentic materials used in distant teaching. In terms of interest, understanding, usefulness, and motivation, most students found that the authentic materials were interesting (73\%) and useful (69\%). In a slightly lower proportion, students believe that authentic materials are motivating, although $34 \%$ of the students found them difficult to understand, especially at the beginning. At the same time, the teachers registered a significant improvement in the students' reaction and participation in online class. Almost all students $(83 \%)$ were ready to contribute to the lessons and were actively involved in performing the tasks.

\section{Discussion}




\subsection{The role of authentic materials}

All the materials selected to complement the online course, that is, magazine articles, u-tube clips, advertisements, posters, business letters were culturally and linguistically rich. In this regard, they provided a fruitful educational environment. The content of the materials selected to fit the learners' immediate concerns influenced positively on their curiosity and involvement [9]. Students were exposed to natural usage of the target language and offered engaging material to be examined. This reflects Tomlinson's [10] view of authentic materials as tools to expose and help students to acquire authentic language use by providing learners with opportunities to use the language while the learners' curiosity and attention is maintained. Moreover, students had to process the provided data to reach a nonlinguistic goal. It is how the texts are used in real life and students were trained to use them in a natural way. According to the notes of one of the teachers:

Authentic materials provide students with actual language in real-life settings, eliminate the gap between the textbooks and the street and help them better manage the natural live communication.

Among the benefits learners have a better opportunity to enhance their grammar and vocabulary as they can notice and study it in real life situations and in this way have better language awareness. It is worth mentioning that audial materials help learners improve their pronunciation. By listening to native speakers students are exposed to natural intonation and melody of speech which contributes to their own production skills and language awareness.

Having implemented the trick with authentic extracts from economic magazines, we showed the students the difference in vocabulary, grammatical structures, and even various spelling.

This extract from a semi-structured interview gives rise to several issues about authentic materials in online classes.

Actually, it is the language native speakers use. Students are supposed to understand such texts eventually and next use them as the final aim of their learning [11]. So, authentic materials bridge the gap between the classroom language and the real language [12].

\subsection{Difficulties}

As mentioned by one of the experimental group teachers:

Authentic input itself in virtual classrooms is not sufficient to enhance learners' involvement and suggests the need to implement those materials within a relevant methodological framework.

Planning to use authentic materials online in a foreign language learning context proved to be a well-thought-out task. As suggested, authentic materials should be represented within a thoroughly designed methodological framework which is aimed at integrating tasks as a way to develop the learners' competence and provide a broader pedagogical context [13]. Such activities enable students to develop both receptive and productive skills and allow them to put into practice what they learned in a meaningful context [14].

Another issue of concern is that authentic materials in the virtual environment can be lexically and grammatically challenging for lower-level students, as they lack the required skills and vocabulary, and so while choosing an authentic text it is important to pay attention to the level of lexis and grammar which is used there [15]. And if we cannot grade the text, we can still grade the task/s to the text making it suitable for the learners [16]. 
Additionally, there is a great number of pre-tasks that introduce students into the topic and connect it with their own life experiences. Besides, in real life information may not be comprehensible in detail at first sight, but in class, an instructor can teach how to deal with such difficulties building up confidence and positive experience.

\section{Conclusion}

In this paper, an attempt has been made to explore the impact of implementing authentic materials in virtual ELT classrooms to enhance students' involvement and improve their overall performance. The results prove that the applied practices help teachers build harmonious and live atmosphere in online classrooms and make both teachers and students feel enthusiastic about the learning process. Nevertheless, given the obtained data it should be highlighted that an appropriate and effective integration of authentic materials in a remote ELT environment greatly depends also on the teacher's experience and pedagogical support offered to learners. This aspect should be further explored in additional research to provide more insight into the best practices in this field.

\section{References}

1. A. Meç, İ. Sağlam Ertem, B. Şener, J Edu, Tech Online Learn, 3(3), 340-362 (2020). https://doi.org/10.31681/jetol.770418

2. A. Nugroho, A. Rekha, D. Ilmiani, Metathesis J Engl Lang Liter Teach, 4(3), 227-291 (2021). https://doi.org/10.31002/metathesis.v4i3.3195

3. C. Zhao, Z. Mei, J Edu Learn, 5(4), 104-112 (2016). https://doi.org/10.5539/jel.v5n4p104

4. A. Gilmore, Lang Teach, 40(02), 97-118 (2007). https://doi.org/10.1017/S0261444807004144

5. P. Davies, E. Pearse, Success in English Teaching (Oxford University Press, Oxford, 2014)

6. J. Harmer, The Practice of English Language Teaching (Longman, London, 1994)

7. M. Peacock, ELT J, 51(2), 144-156 (1997). http://dx.doi.org/10.1093/elt/51.2.144

8. T. Hedge, Teaching and learning in the language classroom (Oxford University Press, Oxford, 2000)

9. P.S. Rao, Shanlax Int J Arts, Sci Human, 7(1), 1-8 (2019). https://doi.org/10.34293/sijash.v7i1.556

10. B. Tomlinson, Lang Teach, 45(2), 143-179 (1998). https://doi.org/10.1017/S0261444811000528

11. L. Lansford, Authentic materials in the classroom: The advantages (2014). Accessed on: October 16, 2021. [Online]. Available:

https://www.cambridge.org/elt/blog/2014/05/16/authentic-materials-classroom-advanta ges/

12. M. Huda, PEOPLE: Int J Soc Sci, 3(2), 1907-1927 (2017).

https://dx.doi.org/10.20319/pijss.2017.32.19071927

13. D. Nunan, Stud Second Lang Acquis, 12(4), 455-456 (1989).

https://doi.org/10.1017/S0272263100009578 
14. Steve, The advantages of using authentic materials in the EFL classroom (2021). Accessed on: October 16, 2021. [Online]. Available:

https://englishcoachonline.com/blog/advantages-of-using-authentic-materials/

15. W.S. Albiladi, Engl Lang Teach, 12(1), 67-77 (2019). https://doi.org/10.5539/elt.v12n1p67

16. W. Guariento, J. Morley, ELT J, 55(4), 347-353 (2001). https://doi.org/10.1093/elt/55.4.347 